\title{
Innovation Manifestations of Competition in Contemporary Concept of Marketing
}

\section{Ovchinnikova T.I.}

\author{
Voronezh State University of Engineering Technologies, Voronezh, Russia
}

Khorev A.I.

Voronezh State University of Engineering Technologies, Voronezh, Russia

Bezrukova T.L.

Voronezh State University of Engineering Technologies, Voronezh, Russia

Salikov Y.A.

Voronezh State University of Engineering Technologies, Voronezh, Russia

Byhonova N.M.

Voronezh State University of Engineering Technologies, Voronezh, Russia

\section{Doi:10.5901/mjss.2015.v6n3s6p53}

\section{Abstract}

The article describes the innovation and innovative manifestations of competition, and changed nature of competition. Authors include market economic mechanisms in innovative manifestations, political innovation - in innovation manifestations, which promote the development of innovative factors. Manifestations of competition are shown as advantages of enterprises in different markets: global, country and regional. Innovative manifestations of competition take into account its postindustrial nature, i.e., dynamics and nonlinear organizations development, which is important in the sanctions imposed to the Russian Federation. It is shown that just systemic changes, such as privatization and de-monopolization, do not mechanistically determine the actions of the competitive environment, they are not conducive to the development of market-based pricing and development of competitiveness of business entities. The problems of the modern concept of marketing are revealed due to the transformation of competitiveness, namely, significant number of its manifestations (unfair, in particular), the lack of harmonization of macroeconomic, microeconomic and regional innovation activities and innovative nature of it. The signs of nature of competition are identified, such as the co-creator of products, individualization of production, the possibility of using nontraditional resources, and others. Practical use of specific signs of the competition manifestation in the organizations of the Voronezh region, such as common values of consumers and producers, the transformation of the role of the consumer, the spread of the process of convergence and also increase of demand for innovation and creating advantage through intellectual components is considered.

Keywords: innovation and innovative manifestations of competition, signs of competition manifestation, marketing concept

\section{Introduction}

Current state of the Russian economy allows us to emphasize the relevance of the study of the latest manifestations of competition in the global market as a whole and to identify the features of competitive relations in Russia in particular. Implementation of the accumulated theoretical and practical research on the problems of competitiveness management of business entities using the latest approaches to the development of marketing innovations will enable many businesses to occupy a leading position in the domestic and world markets.

The aim of this study is to systematize the latest manifestations of competition in modern society that takes into account program limitations and deterrence of the domestic economy, and on this basis, theoretical substantiation of necessity of revision of innovative manifestations of competitiveness of business entities.

Innovative manifestations of competition are the advantages and opportunities of the enterprise, which allow it on 
different markets (global, national, regional, sectoral) to attract an increasing number of consumers.

Marketing concept considering innovative manifestations of competition is based on the main factors - the presence of shared values between the producers and consumers of the products or services that K. Prahalad and V. Ramaswamy define as "the birth of a new reality" (Prahalad, 2005). Its basis is not only knowledge about consumers, but also information technologies used in the enterprise. These authors proposed a revision of the points of view of the nature of the management of organizations with the latest innovative manifestations of competition.

\subsection{Innovative manifestations of competition in the modern marketing concept}

Innovative manifestations of competition in the modern marketing concept taken into account in the management of the companies that operate in the post-industrial society, need to conduct additional research of the nature of competition (as the basis of marketing and its contemporary manifestations), as well as in deep rethinking of the nature and driving forces of the transformation of management systems of domestic economic entities. It should be borne in mind that the management of enterprises in terms of innovation development takes into account the dynamic and nonlinear development of the market environment. The development of market relations in Russia is currently under sanctions ("unfair competition" - such term is used for sanctions by Russian Prime Minister Dmitry Medvedev) should not only lead to the saturation of many segments of the market, but also to the emergence of new market niches. These processes, on the one hand, exacerbate competition and on the other - create a range of different opportunities for businesses operating in the domestic market.

Studies show that systemic economic changes in society include privatization and de-monopolization, but they do not provide mechanistic formation of effective competitive environment, as the level of monopoly, when passing objects from state property into private one, remained the same, de-monopolization without additional accompanying measures did not contribute to the assertion of market pricing mechanism or induce to increase the competitiveness of business entities. The danger for Russia is of its lack of competitiveness in the world rankings. Chance of smoothing the so-called "system separation" from the leading countries is possible at the moment, when the Russian Federation declared policy restrictions by the Russian Federation for the European Union countries, constraining flows of imports. In these conditions it is possible: raising still low capacity of the economy to the development innovation development, the introduction of new technologies, the resolution of the problems of the structural crisis and institutional compatibility of state requirements and private initiative. At the same time in these conditions specificity of competition in the Russian market of innovations can be ensured, that transform the enterprise through intellectual superiority (Fig. 1).

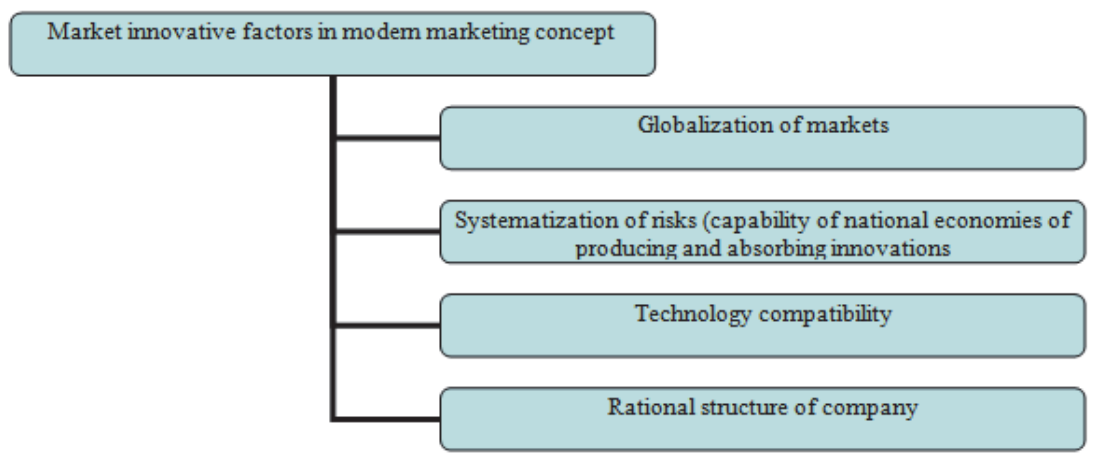

Figure 1. Market factors that promote innovation manifestations in the modern marketing concept taking into account development of intellectual leadership

According to UN statistics, Sweden, Iceland, Denmark, Norway, Switzerland, Finland, Japan had the highest indices of intellectual leadership (and based on them - of competitiveness) in 2006; Russia in this ranking takes the $37^{\text {th }}$ place (Materials of World Data Center for Geoinformatics and Sustainable Development (ICS1J), 2007). Indices of intellectual leadership development were synthesized on the basis of three parameters: the index of the intellectual assets of the company, the index of prospects of society development, the index of the quality of society development. These indices are confirmed by WEF data - in 2006-2007 in the ranking of global competitiveness, Switzerland, Finland, Sweden, Denmark, Singapore, the USA, Japan occupied the first positions, while Russia took the $63^{\text {rd }}$ place, that is 10 points lower than in 2005-2006 (at this, according to the index of innovation factor of global competitiveness Russia also takes the 63 ${ }^{\text {rd }}$ place) (Materials of World Data Center for Geoinformatics and Sustainable Development (ICS1J), 2007). Comparison of 
the factors forming the indices of intellectual superiority and competitiveness, demonstrates the need for the development of domestic economic entities on the basis of innovative manifestations.

\subsection{Theoretical basis of the transformation of innovative nature of competitiveness.}

Let us consider the innovative nature of competitiveness. Under the innovative nature of manifestations of competitiveness we mean fundamental changes in economic systems associated with the inner form of implementation of common economic laws (the law of economy of time, the law of needs improving, the law of growth of labor productivity), which determine the internal dynamics of the economic system of national, regional and institutional levels in any time moment. The innovation nature of economic activities is defined by fundamental acquisitions created in scientific and technical environment of domestic enterprises and research organizations that are associated with specific theoretical and practical schemes of formation and implementation of structural and economic state policy (i.e. political innovations, which are based on the use of administrative resource). Already from characteristics of the innovation and innovative nature of competitiveness it can be concluded that they are interrelated.

Various manifestations of competition are studied by many foreign (Kotler, 1990) and Russian (Bagiev, 2001; Dolgov, 1998; Ovchinnikova, Polyanskaya, Moroz, 2010; Khorev, 2009; Bezrukova \& Drozdova, 2011; Bezrukova T.L. et. al., 2013) scientists and practitioners. However, in the scientific literature there are still no conclusive studies which are theoretical and practical basis of innovative manifestations of competition in the modern marketing concept, which takes into account the processes of transformation of the nature of competition, changes of its forms and consequences of its manifestations.

The necessity of further research of theoretical foundations of transformation of innovative manifestations of competitiveness in the modern concept of marketing results from the following:

- A significant number of problems associated with the modern manifestation of the essence of competition (in particular with such if its manifestations as "unfair competition" relating to sanctions), the formation of new competitive conditions and justification of their consequences for economic entities;

- The presence of a variety of different methods of competitiveness evaluation of the antimonopoly character;

- Insufficient harmonization of macroeconomic, microeconomic and regional innovative activities of innovative and innovation nature of the competitiveness of domestic business entities.

\section{Methods and Approaches}

Competition as a method of accounting market preferences in the management of business entities in the context of rapid changes in the external environment undergoes significant transformation; modern scholars more and more often finds arguments in favor of approval of changes in its nature (Gordon, 2006; Slivotsky, 2006). The study of different approaches to the nature of competition (in addition to the above identified relationship of innovation and innovatics) allows you to select the latest signs of competition in a society based on the development of intellectual activity (Table 1).

Table 1. Types and features of competition nature

\begin{tabular}{ll}
\hline Types of competition & Features \\
\hline Transformation of the consumer role & Consumer - the co-creator of products \\
\hline Resources globalization & High dynamism of migration of capital, labor and other resources \\
\hline Disaggregation and fragmentation of markets & The trend toward individualization of production on customer needs \\
\hline Expanding the horizon and diversity of market & $\begin{array}{l}\text { The struggle for resources (money, time) as the nontraditional potential } \\
\text { opportunities of alternative use of resources by consumers }\end{array}$ \\
\hline Distribution of convergence process & $\begin{array}{l}\text { Formation of non-traditional competitive groups consisting of players of } \\
\text { different economic branches }\end{array}$ \\
\hline $\begin{array}{l}\text { Growing demand for innovations and intensification } \\
\text { of their reuse }\end{array}$ & Creating advantages through intellectual component \\
\hline
\end{tabular}

\section{Results}

The most important feature of competition is the transformation of the role of consumers, which is manifested in the intensification of the search by the companies which create value, in tune with the needs of customers. The inclusion of this sign characterizes the activity of "classical marketing vice versa," i.e., the consumer is able to choose the value of 
their possible products or services himself/herself, and that it affects trade policy of enterprises and the price of goods. Changing the economic thinking of the consumer creates the preconditions for its transformation into not only so-called co-creator of not only the product, but also business process operated by the creation of value. Through the latest media and their versatility (Internet resources, television, print, exhibitions, test actions, etc.) there is transformation of consumer role. For example, the JSC "Voronezh confectionery factory" attracts new consumers to the creation of the latest products by pilot actions when the user selects the favorite products, without knowing its name; JSC "Dairy Plant" Voronezh "has created a website, which receives customer feedback on their products. Another example of consumer participation in the creation of product is preliminary state order of electronic equipment at JSC "Sozvezdie".

Another feature of competition is the individualization of the consumer, which can be both state and individual consumer. Both globalization of markets and disaggregation consider the consumer from the perspective of new approach - namely, like the individual consumer market, which envisages the creation of unique value for everybody. This feature is based on the trend of individualization of production. For example, the JSC "Voronezh Rabbit" meets the needs of each who addressed this company, which produces rabbit meat, liver, rabbit empanadas, dumplings, pies. Everything is produced in an amount which is necessary for the consumer.

\subsection{Indicators of innovative development}

Large enterprises receive (by converting organizations into global networks) new competitive opportunities. In a society based on the intellectual leadership such enterprises produces innovative products demanded by the world. These enterprises include OAO "Sozvezdie", which distributes its defense products around the world, increasing sales through the development of innovations (Table 2).

Table 2. Indicators of innovation development of JSC "Concern"Sozvezdie"

\begin{tabular}{|c|c|c|c|c|}
\hline \multirow{2}{*}{$\begin{array}{l}\text { Key indicator } \\
\text { The indicators of the intensity of innovations } \\
\end{array}$} & \multicolumn{4}{|c|}{2011201320152020} \\
\hline & & & & \\
\hline The ratio of $\mathrm{R} \& \mathrm{D}$ expenditures to sales of products for the period, $\%$ & 14,4 & 6,9 & 8,7 & 6,7 \\
\hline The share of royalty and lump sum payments in the total expenditure, $\%$ & 0,1 & 0,5 & 2 & 7 \\
\hline \multicolumn{5}{|l|}{ The performance indicators of innovations } \\
\hline The average annual growth (to the base 2010) of the growth rate of net income (progressive total), $\%$ & \multicolumn{4}{|c|}{$106,1165,6196,4383,3$} \\
\hline The share of innovative special products in total sales for the period, $\%$ & 35 & 40 & 45 & 50 \\
\hline The share of innovative civil products in total sales for the period, $\%$ & 1 & 2 & 5 & 10 \\
\hline The share of royalty and lump sum payments in revenue, $\%$ & 0 & 0,5 & 2 & 10 \\
\hline \multicolumn{5}{|l|}{ Profitability indicators of innovations } \\
\hline Efficiency of investments in innovative food projects for the period, $\%$ & - & 8 & 10 & 15 \\
\hline Efficiency of investments in innovation technology projects for the period, $\%$ & - & 2 & 3 & 5 \\
\hline \multicolumn{5}{|l|}{ Indicators of innovation of asset structure } \\
\hline The share of intangible assets in total assets, \% & 1,04 & 2,5 & 7 & 15 \\
\hline $\begin{array}{l}\text { The share of intangible assets in the value of the active capital, calculated as the amount of active BPA + } \\
\text { cost of intangible assets, } \%\end{array}$ & 5 & 11 & 25 & 50 \\
\hline
\end{tabular}

Source: Corporation "Sozvezdie", official web-site

\subsection{Tendencies and growth vectors}

Expanding the market of electronic products manufactured by enterprises of the concern, is presented in Figure 3, which indicates "improving" the reputation of not only concern, but also the country as a whole, as a a breakthrough, which is based not on the resource base, and the country breakthrough with the world level of technology that have no analogues in the world.

In large enterprises, such as JSC "Concern" Sozvezdie ", the level of intellectualization of employees grows (R\&D functions, graduate school, number of defended thesis increases every year). At the same time considerable distances between the enterprises of the concern (there are 22 of them) are not the principal obstacle to the development of effective business models.

An important feature of the competition is different vectors. This feature changes the idea of competing companies as of having similarities with the perspective of consumers. Competition continues between industry enterprises before the appearance of non-traditional competitors, while competition takes goods or services which are considered alternative 
or potential substitute of products or services. "The competition is all that buyers believe to be substitutes for goods or services of your company.

Figure 3. The growth in sales of products of concern and continuing trend to growth

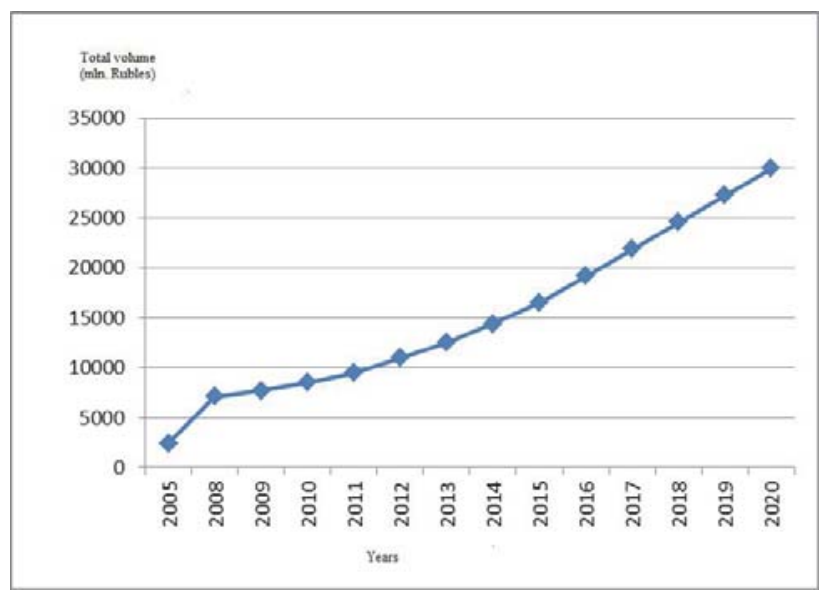

Source: Corporation "Sozvezdie", official web-site

These may be products of the same appearance, with the same functions or benefits. It may be alternative ways to use the money or time resources - they both limit the volume of purchases from your company, "- writes J. Gordon (2006). As an example, we take "Vimm-Bill-Dann" company, which, being engaged in processing of milk, has adapted capacity for production of juices and receives the same income.

\subsection{Value chains and competitive advantages}

As the next sign of competition we believe the establishment of value chain, and their consonance between producers, intermediaries and consumers. Market convergence creates the prerequisites for building competitive an advantage beyond traditional sectors where there are non-traditional competitive groups consisting of different industrial enterprises, while there is a new vector of competition - intrachain competition (competition between value chains). In addition, you can create values within each circuit between its members for leadership and a share of the final award. This transformation of the relations of competition is based on the construction of effective management systems in the chain "consumer - intermediary - manufacturer - supplier of resources" based on such values as achieving the maximum proportion of the final compensation of said chain.

As example we give "Dairy Plant "Voronezhsky", where the value (increase of market share) is pursued by agricultural enterprises for the production of cattle, dairy processing enterprise, and logistics enterprises and, finally, the consumer (as an increase in market share indicates the quality of the products). At any point in the value chain breaks can occur: agriculturists can take their milk to processing by another enterprise (if commodity prices are too low), the processing plant may hire another company to transport by transport (if prices do not satisfy the company), etc. The harmonious combination of goals and incentives characterizes JSC "Dairy Plant "Voronezhsky" as an effective system. You can also include the purpose of advertising or other education company in the value chain. Residents of the region and the country as consumers of dairy products, showing strong demand for it, can affect the volume, pricing, and even the creation of new products (as it happened with soft cheese varieties or baby food).

\subsection{Competitive behavior of market participants and loyalty of clients}

Product demand activates through innovation activity, it is associated with an increase in the proportion of intellectual components in the products and increase of level of unpredictability of the competitive behavior of market participants. In a competitive environment, and, sometimes, unfair competition, which is observed in terms of sanctions, demand for intellectual leadership grows. For the company this factor means the opportunity to obtain fundamentally new competitive advantages. It is known and we wrote about it above that competition - this is not "product against the product", "effectiveness against inefficiency" and "nonlinear" innovation against "linear". Scientists (Anisimov, 2008) note that the 
development and implementation of intellectual capital in domestic enterprises in innovative products is an important component of the efficiency and competitiveness of enterprises, industries and country. Moreover, this process involves not only the development of industries and infrastructure development; it is also due to the development of legislation (innovatics), social security. All this testifies not only about the development of enterprises as generators of production, but also branching of innovative environment with the appropriate infrastructure, legislative and special maintenance.

The nature of competition is also reflected in the penetration of the consumer in the management mechanism of business processes; in case of rejection of the consumer to marketing management value of the goods is reduced. Values, inherent in the product, according to the consumer, must be covered in media, as well as information about the modified components, the technologies of production of goods, etc.

For example, modern technologies to increase customer loyalty are given by us in the management of "Dairy Plant "Voronezhsky" (consumers are turning to the site http://molvest.ru with their proposals). So, according to top managers of "Dairy Plant "Voronezhsky" consumer loyalty programs were attended by 53\% of visitors to the supermarket "Auchan", "World of Taste", "Roundabout" and other.

In the state orders of JSC "Concern "Sozvezdie", which produces electronic products which are in demand on the world market and have no analogues, loyalty of consumers and state is manifested in increase in demand of electronic products.

\section{Conclusion}

The studies confirmed that most businesses are unable to cover their costs for modern methods and technologies of interaction with customers, while consumers believe that they need to profit from meaningful relationships with suppliers (Gordon, 2006). K. Prahalad and V. Ramaswamy draw attention to the need and feasibility of the transition from sectoral and organizational and centric view of the creation of a product, i.e. traditional view of value creation as the exclusive competence of the enterprises, the desire to interact with consumers in a joint value creation. Thus, the consumer is a source and livelihood of enterprise. We agree with the opinion of J. Gordon, who notes: "If you can tell where your business ends and where business of your client begins, then you probably have not yet fully entered the marketing based on relationships" (Gordon, 2006).

Innovative manifestations of competition in the modern marketing concept is primarily based on the common efforts of the consumer and the company, creating new market values using individualized for each customer experience. It is important in the management of modern organizations to rely on marketing innovation, taking into account the needs of individuation, compatibility of innovators and innovation, the optimal structuring of enterprises.

\section{References}

Anisimov, Yu.P. (2008). Innovative approaches to policy harmonization of enterprise /YU.P. Anisimov, E.L. Smolyanova. - Voronezh: VSTA. $240 \mathrm{p}$.

Bagiev, G.L. (2001). International Marketing / G.L. Bagiev, N.K. Moiseeva, S.V. Nikiforov. - St. Pitersburg.

Bezrukova, TL, Drozdova, E.S. (2011). The role of adaptive and innovative marketing strategies for companies in the increasing competition / Journal "Innovation and Investment" - Moscow. No.1. Pp. 55-66.

Bezrukova, T.L., Morkovina S.S., Bezrukov B.A., Popkova E.G. (2013). Methodological Approach to the Identification of Predictive Models of Socio-economic Processes for Investment and Innovative Development of Enterprises / World Applied Sciences Journal. Vol. 26, No. 1. - Pp. 20-27. - Refer.: Pp. 26-27 (9 titl.).

Doyle, P. Management. Strategy and tactics. SPb .: Piter. (1999).

Dolgov, S.I. (1998). Globalization of the economy. New word or new phenomenon. - Moscow: Economics.

Gordon, J. (2006). Target competition. Moscow, "Vershina". Pp. 34-36.

Gordon, J. (2006). Edict. Works. P. 359.

Khorev, A.I. (2009). Improving the model of social and economic systems / A.I. Khorev, Yu.A. Salikov, I.N. Bulgakova. - Voronezh: Herald of the Voronezh State University of Engineering Technologies. 2009. No. 4. Pp. 34-39.

Kotler, F. (1990). Principles of Marketing. - Moscow: Progress.

Materials of World Data Center for Geoinformatics and Sustainable Development (ICS1J). http://wdc.org.ua.

Ovchinnikova, T.I., Polyanskaya I.L., Moroz Yu.A. (2010). Models of transformation of the economic mechanism of corporations in market reforms of independent countries // Transportation business of Russia.No.9(82).Pp.57-60.

Prahalad, K. (2005). Possibilities of competition. Creating unique value for customers / K. Prahalad, V. Ramasvamy. "Start". P.7.

Slivotsky, A. (2006). Migration of values. What will happen to your business the day after tomorrow? M., "Mann, Ivanov and Ferber". Pp. 84-112.

World Economic Forum. (2006). The Global Competitiveness Report, http://www.welbrum.org/pdf/Global_Competi-tiveness_Reports?ger _2006/chapter_II.pdf 